\title{
Risk factors for childbearing during adolescence in a population-based birth cohort in southern Brazil
}

\author{
Denise P. Gigante, ${ }^{1,2,3}$ Cesar G. Victora, ${ }^{3}$ Helen Gonçalves, ${ }^{3}$ \\ Rosângela C. Lima, ${ }^{3}$ Fernando C. Barros, ${ }^{3,4}$ and Kathleen M. Rasmussen ${ }^{2}$
}

Suggested citation: Gigante DP, Victora CG, Gonçalves H, Lima RC, Barros FC, Rasmussen KM. Risk factors for childbearing during adolescence in a population-based birth cohort in southern Brazil. Rev Panam Salud Publica. 2004;16(1):1-10.

ABSTRACT Objective. To use a case-control study to analyze risk factors associated with teenage childbearing among adolescents who were in a birth cohort study that began in 1982 in the city of Pelotas, Rio Grande do Sul, Brazil.

Methods. Adolescent mothers in Pelotas who gave birth between January 1995 and March 2001 and who had been born in 1982 were identified through the local birth information system. These subjects from the 1982 birth cohort were compared to adolescents from the same cohort who had not given birth before March 2001. Standardized interviews were used in 2001 to obtain information about socioeconomic, maternal reproductive, demographic, and lifestyle characteristics. This information was combined with data obtained in earlier phases of this 1982 birth cohort study. Unconditional logistic regression was used to analyze the risk factors associated with childbearing during adolescence.

Results. A total of 420 parous adolescents from the 1982 birth cohort were identified and then compared with 408 cohort adolescents who had not given birth by March 2001. Higher family income in 1982 and more parental schooling in 1982 were inversely related to childbearing among the birth cohort adolescents. Cohort girls whose mothers were under age 20 when they gave birth in 1982 had a higher risk of becoming pregnant while still an adolescent. Cohort girls who, during childhood, lived with siblings from different fathers were twice as likely to become an adolescent mother. Compared to cohort adolescents who had not failed during the first four years of school, those girls who had done so had twice the risk of giving birth during adolescence. Among the cohort girls a positive association was found between younger age at first intercourse and childbearing in adolescence.

Conclusions. The results indicate that the educational level of the adolescent mothers must be considered in planning policies that attempt to disrupt successive cycles of socioeconomic deprivation. Early interventions to improve sex education and to increase the motivation of young girls to achieve higher levels of education are needed. The interventions should aim for a reduction in the risk of long-term poverty and poorer educational achievements of teenage mothers and their children.

Key words Pregnancy in adolescence, socioeconomic factors, risk factors, family characteristics, Brazil.

1 Universidade Federal de Pelotas, Nutrition Department, Pelotas, Rio Grande do Sul, Brazil. Send correspondence to: Denise Petrucci Gigante, Faculdade de Nutrição-UFPEL, Campus UniversitárioCaixa Postal 354, 96010900-Pelotas, RS, Brasil; e-mail: denise@epidemio-ufpel.org.br
2 Cornell University, Division of Nutritional Sciences, Ithaca, New York, United States of America.

3 Universidade Federal de Pelotas, Post-Graduate Program in Epidemiology, Pelotas, Rio Grande do Sul, Brazil.
4 PAHO/WHO Latin American Center for Perinatology and Human Development, Montevideo, Uruguay. 
Teenage pregnancy as a public health problem has been considered controversial (1-5). An analysis of data from 46 developed countries found that adolescent birth rates had declined in the majority of these countries over the 25-year period from 1970 to 1995 (6).

In the United States of America, birth rates among adolescents have decreased since 1970 (7). Between 1990 and 2001, birth rates declined from 60 to 46 births per 1000 girls aged 15-19 years (8). Factors associated with this decrease include positive changes in family environment, improvement in maternal education, stabilization in the proportion of teenagers having sex at an early age, and improved contraceptive use at first intercourse (7).

In the developing countries of Latin America and the Caribbean, data from Demographic and Health Surveys (DHS) from the 1980s and the 1990s showed that the rates of childbearing ranged from 80 to 100 births per 1000 women aged 15-19 years. Comparisons of the DHS data with World Fertility Surveys data from the 1970s showed a decrease in rates in some of these countries from the 1970s to the 1990s. Brazil and Colombia, however, showed increases between the 1980s and the 1990s. In Brazil the rate went from 74 per 1000 women aged 15-19 years in the 1980 s to 86 per 1000 in the 1990s (9). In another analysis of developing countries, Blanc and Way (10) concluded that the length of time between first intercourse and first marriage had increased, exposing young and single women to a greater risk of pregnancy. Adolescents were unlikely to use a contraceptive the first time they had sex and were more likely than older women to experience a contraceptive failure. In Latin America and the Caribbean, current contraceptive use was higher among married than unmarried teens.

The increase in the rates of childbearing in women aged 15-19 years in Brazil between the 1980s and the 1990s contrasted strikingly with a rapid fertility decline overall that has been observed in all regions and all social strata in the country (11). A consis- tent association between higher income and lower fertility has been observed, but important rural-urban and regional differences remain in the fertility decline. For instance, the Northeast, which is Brazil's poorest socioeconomic region, underwent the fastest fertility reduction from the 1970 s to the 1990s. Coupled with lower birth rates at older ages, which are largely due to sterilization (12), the proportion of all births occurring to adolescent mothers increased sharply in Brazil. In the year preceding the 1986 and 1996 DHS, adolescent contribution to overall fertility rose from $9 \%$ to $12 \%$ of all births in the Southeast of Brazil, and from 12\% to $20 \%$ in the Northeast region (12).

Studies carried out in some selected countries have shown that teenage mothers are more likely to have lower educational attainment $(13,14)$ and to come from economically disadvantaged families whose parents had less formal education (15-18). In addition, teenage mothers are more likely to have mothers who themselves had a child in their teens $(15,18,19)$

Having more education is also inversely associated with adolescent childbearing in developing countries. In spite of recent impressive improvements in education levels, fertility rates among adolescents increased between the 1980s and the 1990s in some countries (9).

The consequences of adolescent childbearing have also been related to socioeconomic background. In the 1990s an analysis of findings from three Latin American countries and one country in the English-speaking Caribbean showed that among the poor, adolescent childbearing is associated with lower socioeconomic conditions and poor earning opportunities for teenage mothers (20). In addition, increased risks of adverse outcomes both for adolescent women (for example, pregnancy-induced hypertension and anemia) and their offspring (small for gestational age) are predominantly caused by the social, economic, and behavioral factors that predispose some young women to pregnancy (21). Another review of studies of developing countries found adverse outcomes that included maternal anemia, preterm birth, and cesarean delivery (22).

There is a scarcity of longitudinal data from developing country cohorts that compare adolescent mothers with their peers who delay childbearing. Information collected since birth provides a unique opportunity to assess the effects of socioeconomic background and maternal-child indicators on adolescent health.

To examine the risk factors associated with adolescent childbearing in the city of Pelotas, Brazil, all parous adolescents who belong to the 1982 Pelotas birth cohort study were compared to girls from this same cohort who had not had a child while in their teens. In Brazil, while childbearing during adolescence has been studied from DHS data, there had been no longitudinal study that compared childbearing adolescents with their peers who had not had children. This information about risk factors is particularly important from a public policy perspective. Knowing more about the risk factors could help in planning programs to encourage a reduction in teenage motherhood.

\section{MATERIALS AND METHODS}

This study was carried out in Pelotas, a city located in the state of Rio Grande do Sul, which is the southernmost state in Brazil and which borders on Uruguay and Argentina. Pelotas is relatively affluent among the cities of Brazil. Most of the population are descendants of settlers from Portugal or Spain, along with persons whose ancestors came as slaves from Africa or as immigrants from Germany. The city's population was 214000 in 1982, and about 6000 children were born in the city's three maternity hospitals that year. In 2000 the urban population was 320000 , and the city had five maternity hospitals. The main economic activities of the city are related to agriculture, commerce, and education.

In 1982 all births in the three maternity hospitals in Pelotas were included in a perinatal health survey. The 5914 live-born infants were identified and 
have been contacted several times since then by the research team. Follow-up research carried out in 1984 and 1986 included all the children and studied health, nutrition, and growth. To assess school performance and knowledge about HIV / AIDS a sample was studied in 1995. Sexuality and adolescent health were studied in 1997 and 2001 followup studies. The perinatal study was approved by the maternity hospitals' ethical committees in 1982, and the follow-up studies were approved by the Pelotas Federal University ethical committee.

Verbal informed consent was obtained from parents for all phases of the birth cohort study. In 2001, cases and controls gave their verbal consent to be interviewed. The methods used in the early phases of the study of this cohort have been described elsewhere (23-26).

Pelotas is divided into 265 census tracts, which include an average of 300 households. In the 2001 follow-up study, 70 census tracts were systematically chosen from those in the city; these census tracts represent $27 \%$ of all households. This procedure resulted in a representative sample of the entire urban area and led to locating 1031 subjects (an estimated contact rate of $69 \%$, relative to the original 1982 cohort). Of these 1031 adolescents, 473 of them were female (46\%).

In Pelotas, all live births are recorded through the local live birth information system (Sistema de Informações sobre Nascidos Vivos), and stillborns are identified through the mortality information system (Sistema de Informações sobre Mortalidade). The records on live birth or mortality are necessary to register a birth or to bury a stillborn. The coverage of these systems is considered high. Maternal age is among data that can be obtained through these systems; however, maternal birth date is not available from these data systems. So, all women who gave birth from January 1995 to March 2001 and whose age was compatible with having been born in 1982 were identified in these systems. Hospital delivery records were also reviewed in the city's five maternity wards to confirm the information about maternal date and place of birth. In some cases a visit was made using the address obtained in the hospital, to confirm if the mother belonged to the original cohort. Using this methodology, 446 parous adolescents who had been included in the 1982 cohort study were identified. Twenty-three adolescents could not be located through the address obtained in the systems or maternity records, and 3 refused to participate. The remaining 420 parous teenagers (cases) were compared to 408 adolescents from the 1982 cohort who were located in the 2001 follow-up study and who had not given birth before 31 March 2001 (controls) (Figure 1).

Of the 2876 girls born in 1982, 117 died between 1982 and 2001. In 2001, 729 girls should have been identified in the 70 of the 265 census tracts in the city, but only 496 (68\%) were initially located. Of these 496 girls, 85 of them had children before 2001 and were included in the case group. Among the
411 girls included in the control group there were 2 losses and one refusal. The case group included the 85 adolescents who were identified in the 70 census tracts plus 361 adolescent mothers who were identified using the live birth information system in Pelotas. Among these 446 childbearing adolescents, there were 23 losses and 3 refusals.

In this study, an interviewer-applied questionnaire, a confidential selfadministered questionnaire, and a physical examination (weight, height, and blood pressure) were carried out for all the cases and all the controls in 2001. Interviewers were unaware of the objectives of the study. Quality control included training for fieldworkers and the repetition of around 5\% of the interviews by a fieldwork supervisor. In addition, data were coded daily by interviewers and reviewed by the supervisor. Double entry allowed the correction of possible entry errors.

\section{FIGURE 1. Female adolescents included in the case-control study, Pelotas, Brazil, 2001}

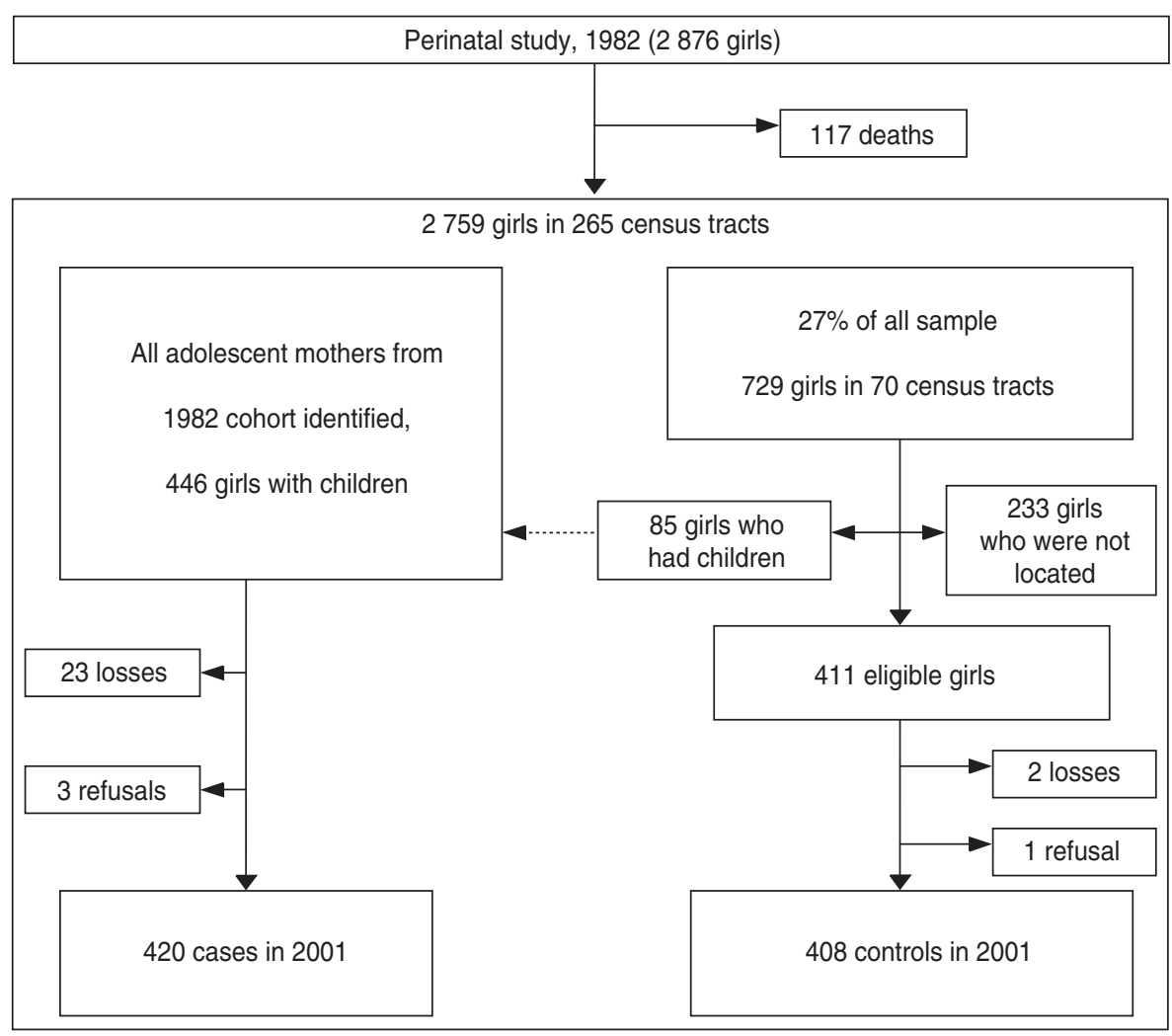




\section{Study variables and data analysis}

Standardized interviews with adolescents and their mothers in 2001 were used to obtain information about socioeconomic, maternal reproductive, demographic, and lifestyle characteristics, along with schooling history, including performance, failure, and dropout. This information was combined with data obtained in earlier phases of this 1982 birth cohort study.

The variables presented in this analysis included family income in 1982 (divided into five groups according to multiples of the minimum wage), maternal and paternal schooling in 1982 (in complete years, grouped in four categories), type of family in 1982 (nuclear, with two generations (mother and/or father and children), or "extensive," with more than two generations; (grandfather and/or grandmother and mother and/or father and children)), and marital status (single or married) of the adolescent's mother in 1982.

In 2001, information was obtained about the presence of the father in the household during childhood, the siblings of different fathers living together during childhood and adolescence, and parental divorce before the girls in the cohort reached adolescence. Maternal age in 1982 (data collected in 1982) was categorized as less than 20 years, 20 to 29 years, or 30 years or more. The skin color of the mothers of the girls in the birth cohort was classified as white or nonwhite, using data collected in 1982. Some maternal religious beliefs practiced during the childhood and adolescence of her daughter were also investigated in 2001, including Catholicism, Protestantism, Spiritism (Kardecism), and African-based Umbanda beliefs. The information about the number of all pregnancies of the girl's mother, including the girl who was born in 1982, was also obtained in the 2001 follow-up. Data on maternal work outside the home during her daughter's childhood and on who looked after the girl during childhood were collected in 1984 and in 1986. In this analysis, the latest information was used. Data from 2001 included the age at menarche for the girls in the birth cohort, age at first "ficar" (typically used as a verb, in Portuguese the word means "to stay"; it is a dating tradition that generally involves hugging and kissing with someone for one or two days, but no sexual relations), and age at first intercourse. The data on these three characteristics were obtained in complete years and grouped in three categories $(<13 ; 13$ or $14 ; 15$ years or more). Also obtained in 2001 were data on whether the cohort girls had siblings who were themselves adolescent parents and on the girls' school failure up to fourth grade (that is, whether the girls repeated one or more of the first four grades of formal schooling).

Unconditional logistic regression was used to determine which factors were associated with risk of childbearing in adolescence. Crude odds ratios were used to describe the relationship between each predictor and the outcome. Adjusted analysis of the determinants associated with adolescent childbearing was accomplished through a hierarchical conceptual model (Figure 2). This

FIGURE 2. Hierarchical model of the determinants associated with adolescent childbearing, Pelotas, Brazil
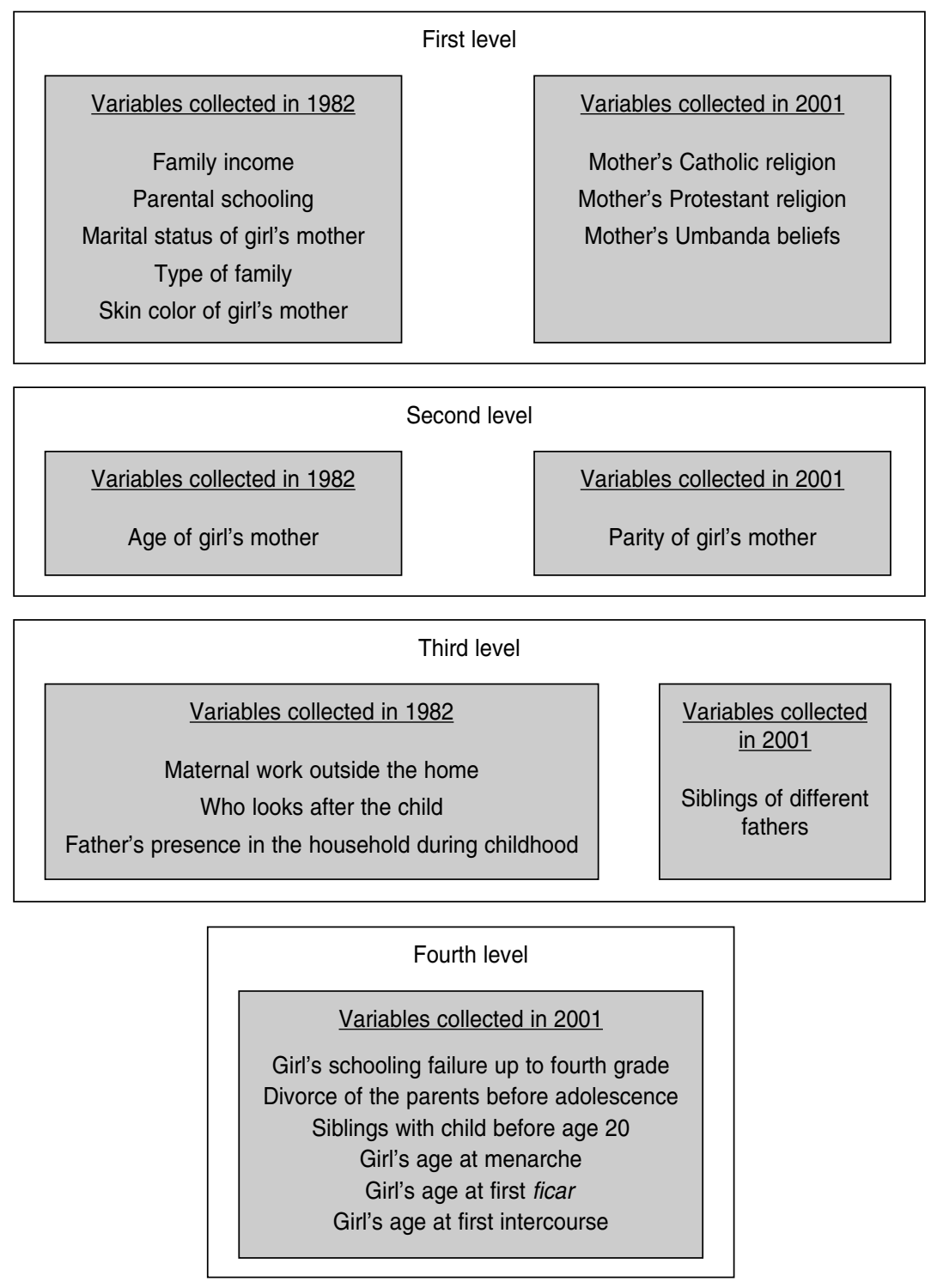
approach takes into account the effect of a risk factor after controlling for confounding factors. The choice of factors to be included in the adjusted analysis is based both on statistical associations as well as on a conceptual framework describing the hierarchical relationships among all risk factors studied (27). One regression equation was fitted in each hierarchical level. The first level included family income, maternal schooling, paternal schooling, type of family, mother's marital status, mother's skin color, and mother's religious beliefs. All variables that had a $P$ value $\leq 0.2$ were included in the next level of the analysis. The variables of the next levels were adjusted for others in the same or higher levels of the hierarchical model. Maternal age and number of pregnancies were in the second level, and the variables describing conditions during the girl's childhood (maternal work, who looks after the child, presence of siblings of different fathers, and father's presence) were included in the third level of the analysis. Finally, the variables describing the girls' conditions during adolescence or earlier (school failure up to fourth grade, divorce of the parents before adolescence, siblings with children before age 20, and age at menarche, first ficar, and first intercourse) were included in the last level. Adjusted odds ratios are presented with $95 \%$ confidence intervals.

\section{RESULTS}

The frequency distributions of cases and controls show the influence of socioeconomic variables on childbearing during adolescence (Table 1). Higher levels of family income, of maternal schooling, and of paternal schooling were all inversely related to childbear- ing. Compared to adolescents in the highest income category (at least 10 times the minimum wage, that is, US\$ 500 per month), those in the lowest income category had 10 times the risk of giving birth. The associations of maternal schooling and of paternal schooling with adolescent childbearing decreased in the adjusted analysis, but the linear trend tests had $P$ values of 0.06 and 0.01 , respectively. The probability of childbearing during adolescence was almost twice as high among girls whose mothers were nonwhite compared to white, in the crude analysis. However, this association disappeared when adjusted for socioeconomic variables.

Some maternal religious beliefs during the childhood and adolescence of her daughter were positively associated with adolescent childbearing in the crude analysis. After adjustment, girls whose mothers had practiced

TABLE 1. Childbearing among adolescents belonging to the Pelotas birth cohort study, according to family socioeconomic characteristics and maternal characteristics at time of girl's birth in 1982, through logistic regression analysis

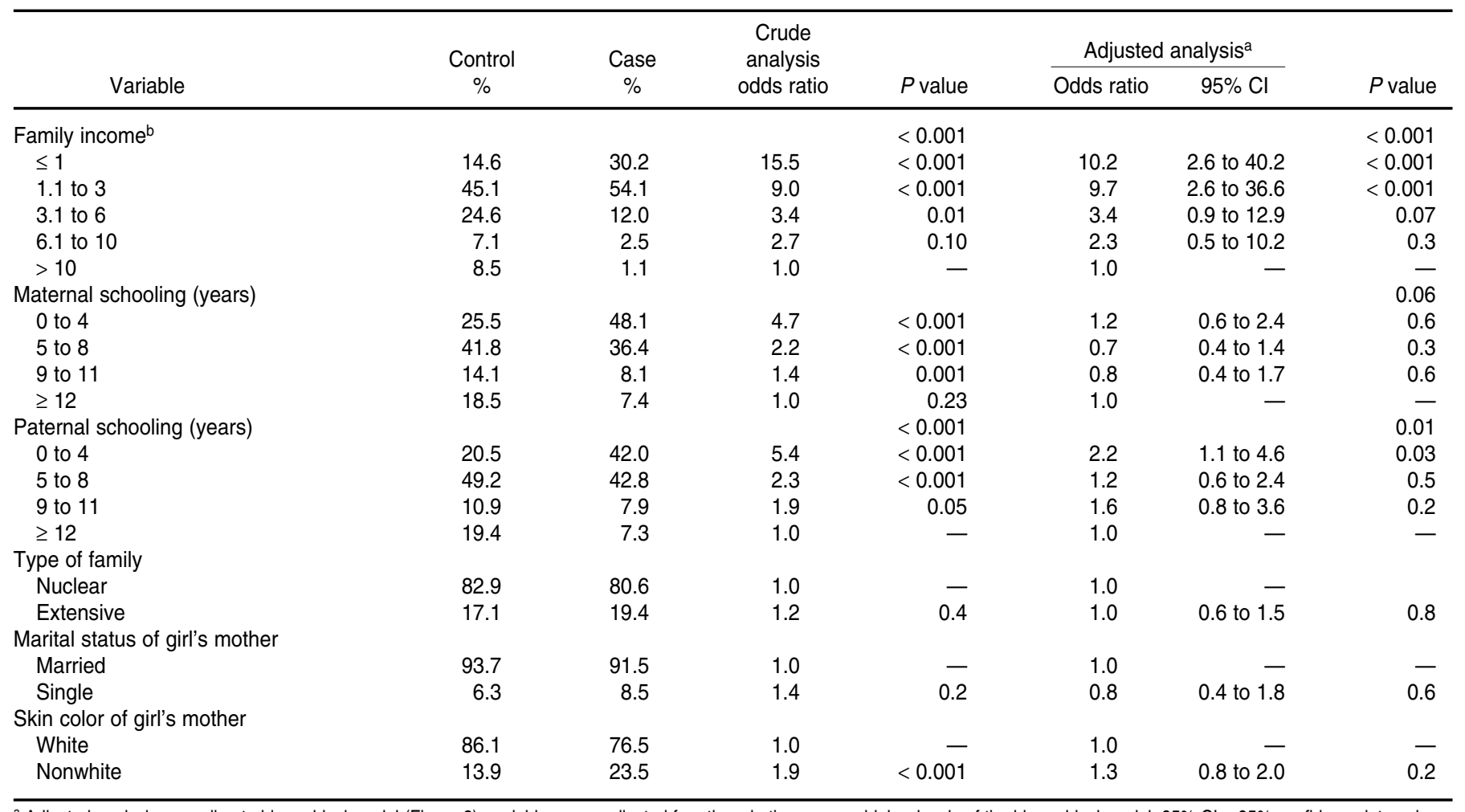

\footnotetext{
${ }^{a}$ Adjusted analysis according to hierarchical model (Figure 2); variables were adjusted for others in the same or higher levels of the hierarchical model; $95 \% \mathrm{Cl}=95 \%$ confidence interval.
}

${ }^{b}$ Family income is given in the number of minimum wage units per month. 
TABLE 2. Childbearing among adolescents belonging to the Pelotas birth cohort study, according to the characteristics of the mothers of those adolescents, through logistic regression analysis

\begin{tabular}{|c|c|c|c|c|c|c|c|}
\hline \multirow[b]{2}{*}{ Variable } & \multirow{2}{*}{$\begin{array}{c}\text { Control } \\
\%\end{array}$} & \multirow{2}{*}{$\begin{array}{c}\text { Case } \\
\%\end{array}$} & \multirow{2}{*}{$\begin{array}{l}\text { Crude } \\
\text { analysis } \\
\text { odds ratio }\end{array}$} & \multirow[b]{2}{*}{$P$ value } & \multicolumn{2}{|c|}{ Adjusted analysis ${ }^{a}$} & \multirow[b]{2}{*}{$P$ value } \\
\hline & & & & & Odds ratio & $95 \% \mathrm{Cl}$ & \\
\hline No & 52.2 & 55.5 & 1.0 & - & 1.0 & - & 一 \\
\hline Yes & 47.8 & 44.5 & 0.8 & 0.4 & 0.9 & 0.6 to 1.4 & 0.7 \\
\hline \multicolumn{8}{|l|}{ Protestant religion } \\
\hline No & 81.4 & 77.6 & 1.0 & - & 1.0 & - & - \\
\hline No & 81.7 & 87.6 & 1.0 & - & 1.0 & - & - \\
\hline Yes & 18.3 & 12.4 & 0.6 & 0.02 & 0.9 & 0.5 to 1.4 & 0.6 \\
\hline \multicolumn{8}{|l|}{ Umbanda beliefs } \\
\hline No & 95.5 & 91.0 & 1.0 & & 1.0 & - & 一 \\
\hline Yes & 4.5 & 9.0 & 2.1 & 0.01 & 2.2 & 1.1 to 4.5 & 0.02 \\
\hline \multicolumn{8}{|l|}{ Parity of girl's mother } \\
\hline 6 or more & 17.3 & 33.9 & 3.2 & $<0.001$ & 2.9 & 1.3 to 6.2 & 0.008 \\
\hline Age of girl's mother (yr) in 1982 & & & & 0.001 & & & 0.04 \\
\hline$<20$ & 13.4 & 19.1 & 2.1 & $<0.001$ & 1.7 & 1.0 to 3.0 & 0.05 \\
\hline 20 to 29 & 52.8 & 57.6 & 1.6 & 0.004 & 1.7 & 1.2 to 2.6 & 0.008 \\
\hline 30 or more & 33.8 & 23.3 & 1.0 & - & 1.0 & - & - \\
\hline
\end{tabular}

${ }^{a}$ Adjusted analysis according to hierarchical model (Figure 2); variables were adjusted for others in the same or higher levels of the hierarchical model; $95 \% \mathrm{Cl}=95 \% \mathrm{confidence}$ interval.

Umbanda religious beliefs were about twice as likely to become a mother during adolescence. The higher a mother's parity as of 2001, the more likely her daughter was to become pregnant during adolescence. In addition, adolescents whose mothers were teenagers when they gave birth in 1982 were almost twice as likely to become pregnant during adolescence (Table 2).

The absence of the father in the household during childhood was not associated with childbearing during adolescence. However, girls who had siblings of different fathers were about twice as likely to become mothers during adolescence (Table 3).

Most of the variables related to the girls' characteristics during childhood or adolescence that were collected in 2001 were associated with childbearing during adolescence in the crude analysis (Table 4). Compared to girls who had not failed during the first four grades of school, those who had failed had twice the risk of giving birth during adolescence. On the other hand, the crude effects of divorce of the parents or of having siblings who had had children before age 20 disappeared in the adjusted analysis. Finally, and not surprisingly, there was a significant association between younger age at first intercourse and childbearing during adolescence.

\section{DISCUSSION}

This study has some limitations that need to be considered when interpreting the results. Losses during followup since 1982 have been about 30\%. Analyses of the baseline characteristics of those who were lost showed that they did not differ markedly in terms of birthweight, maternal schooling, or maternal skin color. The strategy of visiting every household in a sample of census tracts, coupled with the very low rate of refusals $(0.5 \%)$ among adolescents who were identified in 2001, suggests that losses were due either to out-migration to other cities or to fail- ure to report the presence of a cohort member to the interviewers.

As mentioned earlier, the cases were selected based on the information systems for live births and for stillbirths. Because these records are necessary to register a birth or to bury a stillborn, it is very likely that all cohort members who had had a delivery and who still lived in Pelotas were included; $94.6 \%$ of those identified were successfully interviewed.

Observational studies may be affected by various biases (28), including recall bias. In this study, recall bias is unlikely because most retrospective data were collected near the time it had happened, in earlier phases of the birth cohort study. Although another limitation might be selection bias, the fact that both cases and controls belong to the same cohort makes this unlikely.

It should be stressed that this study refers to adolescent childbearing, and not to adolescent pregnancy. Although elective induced abortions are illegal 
TABLE 3. Childbearing among adolescents belonging to the Pelotas birth cohort study, according to the girl's childhood characteristics, through logistic regression analysis

\begin{tabular}{|c|c|c|c|c|c|c|c|}
\hline \multirow[b]{2}{*}{ Variable } & \multirow{2}{*}{$\begin{array}{c}\text { Control } \\
\%\end{array}$} & \multirow{2}{*}{$\begin{array}{c}\text { Case } \\
\%\end{array}$} & \multirow{2}{*}{$\begin{array}{c}\text { Crude } \\
\text { analysis } \\
\text { odds ratio }\end{array}$} & \multirow[b]{2}{*}{$P$ value } & \multicolumn{2}{|c|}{ Adjusted analysis $^{a}$} & \multirow[b]{2}{*}{$P$ value } \\
\hline & & & & & Odds ratio & $95 \% \mathrm{Cl}$ & \\
\hline No & 53.4 & 47.2 & 1.0 & - & 1.0 & - & - \\
\hline Yes & 46.6 & 52.8 & 1.3 & 0.08 & 1.1 & 0.7 to 1.8 & 0.8 \\
\hline Who looks after the child & & & & 0.18 & & & 0.17 \\
\hline Mother & 64.2 & 62.7 & 1.0 & - & 1.0 & - & - \\
\hline \multicolumn{8}{|l|}{ Siblings of different fathers } \\
\hline No & 82.5 & 64.3 & 1.0 & - & 1.0 & - & - \\
\hline Yes & 17.5 & 35.7 & 2.6 & $<0.001$ & 1.8 & 1.2 to 2.9 & 0.006 \\
\hline \multicolumn{8}{|c|}{ Presence of the father in the household } \\
\hline No & 10.2 & 16.7 & 1.4 & 0.16 & 2.0 & 0.6 to 6.5 & 0.3 \\
\hline Yes & 89.8 & 83.3 & 1.0 & - & 1.0 & - & - \\
\hline
\end{tabular}

${ }^{a}$ Adjusted analysis according to hierarchical model (Figure 2); variables were adjusted for others in the same or higher levels of the hierarchical model; $95 \% \mathrm{Cl}=95 \%$ confidence interval.

in Brazil, they are widely available in Pelotas (29). Differences in access to abortions may explain part of the social differentials, such as family income and paternal schooling, that were observed in this study. Given the absence of reliable information on induced abortions, it is not possible to estimate how much this may have affected our results.

This study has shown differences among subgroups of the girls in the probability of becoming a mother during adolescence. Adolescents who had a child were more likely to be in a lower socioeconomic level, in terms of lower family income and less parental schooling. However, in the adjusted

TABLE 4. Childbearing among adolescents belonging to the Pelotas birth cohort study, according to girl's childhood and adolescent characteristics, through logistic regression analysis

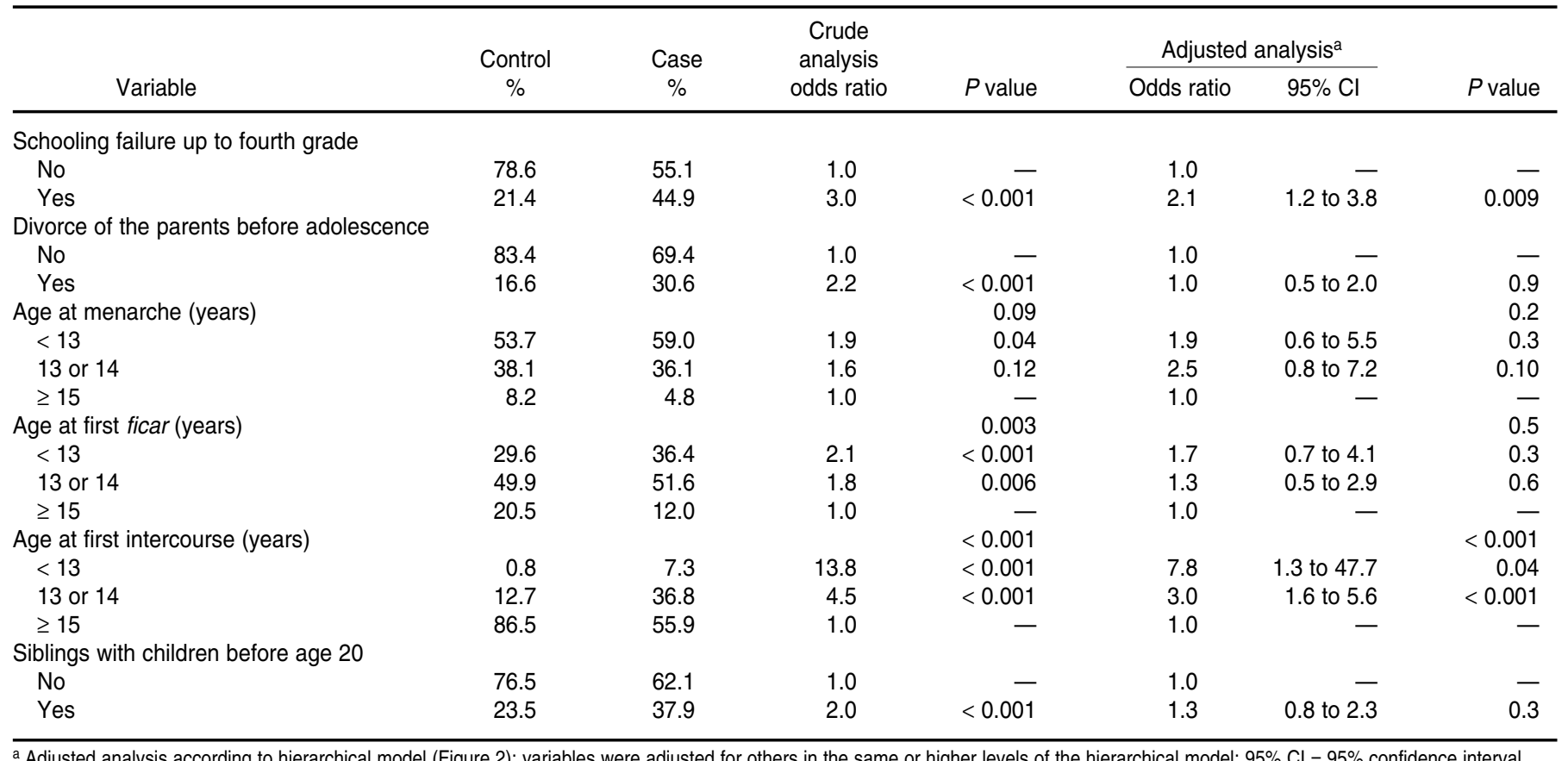


analysis, maternal education showed borderline significance. This effect may have been attenuated by the inclusion of paternal schooling in the same level of the hierarchical conceptual model, suggesting that the effect of maternal schooling is not independent of other socioeconomic variables. A longitudinal study in the United Kingdom (15) showed that familial financial difficulties increased the probability of teenage motherhood. A low socioeconomic level for the family was also associated with teenage pregnancy in Taiwan (30) and in the United States (16).

Some studies $(16,18)$ have shown that teenage mothers are more likely to belong to a single-parent or dysfunctional family. However, in our study three related variables (type of family, single mother, and presence of the father in the household during childhood) were not associated with childbearing in adolescence, and the possible contribution of divorce of the parents disappeared in the adjusted analyses. These results for Pelotas were similar to ones that the National Survey of Sexual Attitudes and Lifestyles found in the United Kingdom (31).

The association of childbearing during adolescence with maternal skin color disappeared in our adjusted analysis. That was also seen in another Brazilian study, in the northeastern part of the country (12). The analysis of data from 1986, 1991, and 1996 Demographic Health Surveys confirms that other economic and demographic factors, particularly education, largely capture any observed fertility differentials between white and nonwhite adolescents in northeastern Brazil. Ethnicity is a determinant of access to education and of income levels in Brazilian families (32). Therefore, the fact that ethnic differences are reduced after adjusting for socioeconomic factors indicates that the effect of skin color is mediated by the other maternal variables. Mediating factors are not true confounding factors $(27,28)$ and should not be included in a model estimating the full effect of a determinant.

An unexpected finding of our analyses was the increased likelihood of childbearing among adolescents whose mothers had Umbanda religious beliefs. The effect of maternal religious affiliation on adolescent fertility was also identified in northeastern Brazil, where data from 1986 indicated that non-Catholics were at higher risk $(P<$ 0.001); however, the differences in 1991 and 1996 were not statistically significant (12). A study in Ecuador (17) found that "religiosity" was higher among nonpregnant adolescents; however, these findings were not adjusted for socioeconomic variables. A protective effect of Kardecism on childbearing during adolescence was seen in our crude analysis, but it disappeared after adjustment for confounding.

Other studies have also found associations between teenage pregnancy and characteristics of the adolescents' mothers, including parity and age at first delivery $(15,16,18)$.

Other studies have shown the effect of family background, including socioeconomic characteristics and functional characteristics such as families' and adolescents' resources for resolving conflicts. However, the association between having siblings of different fathers and childbearing during adolescence had not been described in earlier literature.

Several studies have shown that less education is the factor that has been most strongly and consistently associated with childbearing during adolescence $(12,14,15,30)$. However, the authors of these studies were not able to determine whether poor educational attainment of the adolescent mother is a consequence of influences that precede early childbearing or of factors that result from early childbearing. One longitudinal study (13) showed that teenage childbearing was a factor that was inversely associated with completing high school. However, other socioeconomic factors, such as maternal education and race, were also associated with both greater likelihood of early childbearing and lower likelihood of school completion. To avoid reverse causality bias, we included failure in the first four years of school in our analysis. Our results clearly showed that girls who had failed dur- ing the first years of school were more likely to give birth during adolescence. A better understanding of the associations among teenage pregnancy, schooling failure, and dropping out of school could be obtained through an analysis that included more detailed information in terms of the temporality of these events.

As might be expected, girls who had sexual intercourse early also began childbearing early. This was also found in the United Kingdom in the National Survey of Sexual Attitudes and Lifestyles (31).

In conclusion, our analyses showed that there was a striking influence of family background on the occurrence of childbearing during adolescence. These findings suggest the need to pay more attention to female adolescents who come from a lower socioeconomic level and whose mothers practice Umbanda religious beliefs, have many children, or were teenage mothers themselves. In addition, adolescents who have siblings of different fathers, who failed in school by the fourth grade, or who had their first sexual intercourse before age 15 should also receive more attention in adolescent health programs. These results provide information for designing adolescent pregnancy prevention programs and indicate that the educational level of adolescent mothers must be considered in planning policies that attempt to disrupt successive cycles of socioeconomic deprivation. Reducing teenage childbearing rates could be achieved by improving sex education and increasing the motivation of young girls to achieve higher levels of education. Early interventions are needed, given the high proportion of girls who fail in the first years of school. The interventions should seek a reduction in the risk of long-term poverty and of poorer educational achievements of teenage mothers and of their children.

Acknowledgment. This study was supported by the Fundação de Amparo à Pesquisa no Rio Grande do Sul (FAPERGS), the Coordenação de Aperfeiçoamento de Pessoal de Nível Superior (CAPES) of Brazil, and the World Health Organization. 


\section{REFERENCES}

1. Lawlor D, Shaw M, Johns S. Teenage pregnancy is not a public health problem. BMJ. 2001;323:1428-9.

2. Lawlor DA, Shaw M. Too much too young? Teenage pregnancy is not a public health problem. Int J Epidemiol. 2002;31(3):552-4.

3. Scally G. Too much too young? Teenage pregnancy is a public health, not a clinical, problem. Int J Epidemiol. 2002;31(3):554-5.

4. Rich-Edwards J. Teen pregnancy is not a public health crisis in the United States. It is time we made it one. Int J Epidemiol. 2002;31(3): 555-6.

5. Smith S. Too much too young? In Nepal more a case of too little, too young. Int J Epidemiol. 2002;31(3):557-8.

6. Singh S, Darroch JE. Adolescent pregnancy and childbearing: levels and trends in developed countries. Int Fam Plan Perspect. 2000; 32(1):14-23.

7. Manlove J, Terry E, Gitelson L, Papillo AR, Russell S. Explaining demographic trends in teenage fertility, 1980-1995. Int Fam Plan Perspect. 2000;32(4):166-75.

8. Macdorman MF, Minino AM, Strobino DM, Guyer B. Annual summary of vital statistics2001. Pediatrics. 2002;110(6):1037-52.

9. Singh S. Adolescent childbearing in developing countries: a global review. Stud Fam Plan. 1998;29(2):117-36.

10. Blanc AK, Way AA. Sexual behavior and contraceptive knowledge and use among adolescents in developing countries. Stud Fam Plan. 1998;29(2):106-16.

11. Martini G. Brazil's fertility decline, 1965-95: a fresh look at key factors. Popul Dev Rev. 1996; 22(1):47-75.

12. Gupta N, Leite IC. Adolescent fertility behavior: trends and determinants in Northeastern Brazil. Int Fam Plan Perspect. 1999;25(3):125-30.

13. Ahn N. Teenage childbearing and high school completion: accounting for individual het- erogeneity. Int Fam Plan Perspect. 1994;26(1): 17-21.

14. Bradley T, Cupples ME, Irvine H. A case control study of a deprivation triangle: teenage motherhood, poor educational achievement and unemployment. Int J Adolesc Med Health. 2002;14(2):117-23.

15. Kiernan KE. Becoming a young parent: a longitudinal study of associated factors. Brit J Sociol. 1997;48(3):406-28.

16. Manlove J. The influence of high school dropout and school disengagement on the risk of school-age pregnancy. J Res Adolesc. 1998;8(2):187-220.

17. Guijarro S, Naranjo J, Padilla M, Gutierrez R, Lammers C, Blum RW. Family risk factors associated with adolescent pregnancy: study of a group of adolescent girls and their families in Ecuador. J Adolesc Health. 1999;25:166-72.

18. Lee MC. Family and adolescent childbearing. J Adolesc Health. 2001;28(4):307-12.

19. Manlove J. Early motherhood in an intergenerational perspective: the experience of a British cohort. J Marriage Fam. 1997;59(2): 263-79.

20. Buvinic M. The costs of adolescent childbearing: evidence from Chile, Barbados, Guatemala, and Mexico. Stud Fam Plan. 1998;29(2): 201-9.

21. Cunnington AJ. What's so bad about teenage pregnancy? J Fam Plan Rep Health Care. 2001; 27(1):36-41.

22. Scholl TO, Hediger ML, Belsky DH. Prenatal care and maternal health during adolescent pregnancy: a review and meta-analysis. J Adolesc Health. 1994;15(6):444-56.

23. Barros FC, Victora CG, Vaughan JP, Tomasi E, Horta BL, Cesar JA, et al. The epidemiologic transition in maternal and child health in a Brazilian city, 1982-1993: a comparison of two population-based cohorts. Paed Perinatal Epidemiol. 2001;15:4-11.
24. Barros FC, Victora CG, Vaughan JP. The Pelotas birth cohort study, 1982-1987. Strategies for following up 6,000 children in a developing country. Paed Perinatal Epidemiol. 1990;4:267-82.

25. Victora CG, Barros FC, Lima RC, Behague DP, Gonçalves H, Horta BL, et al. The Pelotas birth cohort study, Rio Grande do Sul, Brazil 1982-2001. Cad Saude Publica. 2003;19:1241-56.

26. Victora CG, Barros FC, Vaughan JP. Epidemiología de la desigualdad. Washington, D.C.: Organización Panamericana de la Salud; 1992.

27. Victora CG, Huttly SR, Fuchs SC, Olinto MT. The role of conceptual frameworks in epidemiological analysis: a hierarchical approach. Int J Epidemiol. 1997;26(1):224-7.

28. Rothman KJ, Greenland S. Modern epidemiology. Philadelphia: Lippincott-Raven; 1998.

29. Olinto MTA, Galvão LW. Características reprodutivas de mulheres de 15 a 49 anos: estudos comparativos e planejamento de ações. Rev Saude Publica. 1999;33(1):64-72.

30. Wang RH, Wang HH, Hsu MT. Factors associated with adolescent pregnancy-a sample of Taiwanese female adolescents. Publ Health Nurs. 2003;20(1):33-41.

31. Wellings K, Wadsworth J, Johnson A, Field J, Macdowall W. Teenage fertility and life chances. Rev Reprod. 1999;4(3):184-90.

32. Olinto MTA, Olinto BA. Raça e desigualdade entre as mulheres: um examplo no sul do Brasil. Cad Saude Publica. 2000;16(4):1137-42.

Manuscript received 12 September 2003. Revised version accepted for publication 12 March 2004.

RESUMEN Objetivo. Utilizar un estudio de casos y testigos para analizar los factores de riesgo asociados con ser madre adolescente en un grupo de jóvenes que participaron en un estudio de cohorte iniciado en 1982 en la ciudad de Pelotas, Rio Grande do Sul, Brasil.

Factores de riesgo asociados con ser madre adolescente en una cohorte de nacimiento tomada de la población en el sur del Brasil
Métodos. Por medio del sistema local de datos de natalidad, se identificó a todas las madres adolescentes en Pelotas que habían dado a luz entre enero de 1995 y marzo de 2001 y que habían nacido en 1982. Estas mujeres de la cohorte de 1982 se compararon con adolescentes de su misma cohorte que no habían dado a luz antes de marzo de 2001. En 2001 se aplicaron entrevistas estandarizadas para recoger información sobre las características socioeconómicas, reproductivas, demográficas y de estilo de vida de las mujeres. Dicha información se combinó con datos obtenidos en fases más tempranas del estudio de la cohorte de 1982. Se empleó un modelo de regresión logística incondicionada para analizar los factores de riesgo asociados con dar a luz durante la adolescencia.

Resultados. Un total de 420 adolescentes parturientas de la cohorte de 1982 fueron identificadas y comparadas con 408 adolescentes de la misma cohorte que no habían dado a luz antes de marzo de 2001. Se observó entre las adolescentes de la cohorte que tener un ingreso familiar más alto y padres con una mayor escolaridad se asociaban inversamente con dar a luz. Las jóvenes de la cohorte cuyas madres no habían cum- 
plido los 20 años de edad cuando dieron a luz en 1982 mostraron un riesgo mayor de ser madres adolescentes. Las jóvenes de la cohorte que durante la niñez habían vivido con hermanos que eran hijos de distintos padres mostraron un riesgo doble de ser madres adolescentes. Cuando se compararon con adolescentes que no habían suspendido las clases en los primeros cuatro años de asistir a la escuela, las que sí las habían suspendido tuvieron el doble del riesgo de dar a luz durante la adolescencia. En las jóvenes pertenecientes a la cohorte el haber tenido la primera relación sexual a una edad más temprana se asoció directamente con dar a luz en la adolescencia.

Conclusiones. Los resultados del estudio indican que la escolaridad de las madres adolescentes debe tomarse en cuenta a la hora de planificar políticas orientadas a interrumpir ciclos sucesivos de privación económica. Hacen falta intervenciones tempranas para mejorar la educación sexual y hacer que las jovencitas tengan mayores motivaciones para alcanzar una mayor escolaridad. Las intervenciones deben encaminarse a reducir el riesgo de que las madres adolescentes y sus hijos acaben viviendo en la pobreza y sin recibir una educación adecuada.

\section{Encuentro de Investigación en Enfermería 8th Nursing Research Conference}

Fecha/Dates: 17 al 20 de noviembre de 2004/17-20 November 2004

Lugar/Place: Hospital Universitario Virgen del Rocío, Sevilla, España/Hospital Universitario Virgen del Rocío, Seville, Spain

EI VIII Encuentro de Investigación en Enfermería lo organiza la Unidad de Coordinación y Desarrollo de la Investigación en Enfermería del Instituto de Salud Carlos III (Investén-isciii), organismo público adscrito al Ministerio de Sanidad y Consumo de España. Entre los temas propuestos para los pósteres y las mesas redondas figuran los siguientes: envejecimiento y salud; atención de pacientes con cáncer; cuidados de salud en niños y adolescentes; enfermedades crónicas; salud comunitaria; cuidado de los enfermos críticos; cuidados paliativos; práctica basada en la evidencia y utilización de la investigación; aplicación de las nuevas tecnologías a la salud; promoción de la salud y educación para la salud; VIH/SIDA y otras enfermedades infecciosas; salud e inmigración; cuidados maternoinfantiles; gestión en enfermería; docencia en enfermería; medida de los resultados de salud; enfermería y salud mental; métodos de investigación; variabilidad en la práctica clínica; enfermería y genética; implicaciones para la enfermería de la violencia y el maltrato de las mujeres, los niños y los ancianos; cuidados de salud en las mujeres; y dilemas y conflictos éticos.

El 17 de noviembre se realizarán diversos talleres relacionados con la metodología de la investigación. Las tarifas de inscripción son las siguientes: inscripción normal, 210 ; ponentes y personal del Hospital Virgen del Rocío, 180 ; estudiantes de enfermería de primer ciclo y becarios del ISIII, 130 .

The 8th Nursing Research Conference is being sponsored by the Unit for Coordination and Development of Nursing Research of the Instituto de Salud Carlos III (Investén-isciii), a public entity belonging to the Spanish Ministry of Health. Suggested topics for posters and concurrent sessions include: aging and health; cancer care; child/adolescent health; chronic illness; community/home/ public health; critical care; end-of-life/palliative care; evidence-based practice/research utilization; health informatics; health promotion; HIV/AIDS and infectious diseases; health of indigenous peoples; midwifery and women's health; nursing management; nursing education; outcome measures; nursing and mental health; research methods; variability in clinical practice; nursing and genetics; violence and abuse of women and children; implications of nursing; women's health care; and ethical dilemmas and conflicts.

Workshops on research methodology will be held on 17 November. Registration fees will be as follows: congress registration, 210 ; presenters and staff of ISCIII, 180 ; beginning nursing students and fellows of the ISCIII, 130 .

\section{Información/Information:}

Teresa Moreno Casbas

Unidad de Coordinación y Desarrollo de la Investigación en Enfermería

Subdirección General de Investigación Sanitaria

Pabellón 3. Instituto de Salud Carlos III

C/ Sinesio Delgado, 628029 Madrid, España

Tel.: 34-918-222546 / 2536 / 2539 / 2542 / 2517

Fax: 913877897

Correo electrónico/e-mail: mmoreno@isciii.es

Página web/Web site: www.isciii.es/investen 